\title{
Co-firing coal and biomass blends and their influence on the post-combustion $\mathrm{CO}_{2}$ capture installation
}

\author{
Angelika Więckol-Ryk ${ }^{1, *}$, and Adam Smoliński ${ }^{2}$ \\ ${ }^{1}$ Central Mining Institute, Department of Risk Assessment in Industry, Katowice, Poland \\ ${ }^{2}$ Central Mining Institute, Department of Energy Saving and Air Protection, Katowice, Poland
}

\begin{abstract}
Co-firing of biomass with coal for energy production is a well-known technology and plays an important role in the electricity sector. The post-combustion capture integrated with biomass-fired power plants (Bio-CCS) seems to be a new alternative for reducing greenhouse gas emissions.

This study refers to the best known and advanced technology for post-combustion $\mathrm{CO}_{2}$ capture (PCC) based on a chemical absorption in monoethanolamine (MEA). The co-firing of hard coal with four types of biomass was investigated using a laboratory fixed bed reactor system. The comparison of gaseous products emitted from the combustion of coal and different biomass blends were determined using gas chromatography.

Research proved that co-firing of biomass in fossil fuel power plants is beneficial for PCC process. It may also reduce the corrosion of $\mathrm{CO}_{2}$ capture installation. The oxygen concentration in the flue gases from hard coal combustion was comparable with the respective value for a fuel blend of biomass content of $20 \% \mathrm{w} / \mathrm{w}$. It was also noted that an increase in biomass content in a sample from 20 to $40 \% \mathrm{w} / \mathrm{w}$ increased the concentration of oxygen in the flue gas streams. However, this concentration should not have a significant impact on the rate of amine oxidative degradation.
\end{abstract}

\section{Introduction}

Combustion of biomass and coal for power production helps to reduce greenhouse gas (GHG) emissions from the existing coal-fired power plants. Carbon dioxide, methane, nitrous oxide and perfluorocarbons are the main anthropogenic sources of GHG. For the electricity sector, co-firing of biomass with fossil fuels has a positive impact on $\mathrm{CO}_{2}$ reduction since it is counted as neutral. Biomass has quite different chemical composition in comparison with hard coal, that is why burning it with coal blends also reduces $\mathrm{NO}_{\mathrm{x}}$ and $\mathrm{SO}_{\mathrm{x}}$ levels. Co-firing has a positive influence on the environment and economy depending on the chemical composition of the biomass used [1]. It minimizes the amount of waste, soil and water pollution and may also reduce fuel costs.

Recent studies [2,3] have shown that integrated $\mathrm{CO}_{2}$ capture and storage (CCS) with biomass-fired power plant is also considered. Enforcing CCS in combination with biomass co-firing power plants provides a further possibility of reducing $\mathrm{CO}_{2}$ emissions for the electricity [4]. Nowadays, there is an on-going discussion about positive and negative aspects of incorporating CCS into biomass-fired power plants. One of the reasons behind current studies is to find the answer to the following question: "Would the incorporated CCS with biomass fired power plant be an attractive option to further minimalize the cost of $\mathrm{CO}_{2}$ and generate an additional revenue as $\mathrm{CO}_{2}$ credit?" [3].

In 2014, greenhouse gas emissions were reduced by $22.9 \%$ compared with the ones in 1990 in 28 Member States of the European Union (EU-28). The overall highest GHG emissions of the EU-28 were in Germany $(21.9 \%)$ and the lowest in Malta $0.08 \%$. Poland was 24th in terms of the amount of GHG emissions (8.64\%) and it overtook Italy $(9.69 \%)$, France $(10.76 \%)$, the United Kingdom (12.6\%) and aforementioned Germany. The greenhouse gas emissions in Poland in 2014 were reduced by $19.3 \%$ when compared with 1990 [5]. After the recent ratification, the EU target is to reduce GHG levels by at least $20 \%$ until 2020 and $40 \%$ until 2030 . The proposed legislation includes tightening the EU Emissions Trading System (ETS) for the period after 2020.

At present, $\mathrm{CO}_{2}$ fees and ETS credit to cover its $\mathrm{CO}_{2}$ emissions allows EU-28 to stabilize energy price. From 2008 to 2014, the cost of unit $\mathrm{CO}_{2}$ emission increased by $21 \%$ and stayed at the same level for the last two years [6]. However, calculation of $\mathrm{CO}_{2}$ emissions and Green Certificates shows that the price may increase significantly in the future. One of the theoretical price scenarios of the U.S. Environmental Protection Agency's (EPA) set Low, Mid, and High case forecasts for $\mathrm{CO}_{2}$ prices. The $\mathrm{CO}_{2}$ price per ton according to forecast will increase from $\$ 15$ to $\$ 25$ in 2022 , from $\$ 21$ to $\$ 43$ in 2030 and from $\$ 36$ to $\$ 110$ in 2050 . In order to avoid paying such high fees, it seems to be effective to carry

Corresponding author: awieckol@gig.eu 
out further research on CCS incorporated into biofuels. The IEA confirms that the cost of reducing GHG without CCS would be over $70 \%$ [2]. The combination of $\mathrm{CO}_{2}$ capture with sustainable biomass conversion (Bio-CCS) seems to be the only large scale and the most promising technology that can remove $\mathrm{CO}_{2}$ from the atmosphere. It has already been raised in the discussion over the EU Energy Roadmap 2050.

It was presented that currently carbon capture and storage (CCS) is at a phase of demonstration but in the future it could be applied to various energy plants, especially incorporating co-firing or co-gasification of sustainable biomass feedstock, or $100 \%$ biomass energy plants, biofuel production facilities or bio refineries.

The aim of this study is to analyse and describe the co-firing process of biomass with coal and to present its influence on capturing $\mathrm{CO}_{2}$ from the flue gases by chemical absorption.

\section{Biomass combustion with $\mathrm{CO}_{2}$ capture}

Combustion of biomass with fossil fuels has a good influence on the environment and the economy of power generation. Carbon dioxide is emitted into the atmosphere during biomass fuels burning, yet $\mathrm{CO}_{2}$ is also absorbed during its growth thus the combustion of biomass is considered to be $\mathrm{CO}_{2}$-neutral.

The main components of biomass are carbon, oxygen and hydrogen but they also contain nitrogen, sulphur and small amounts of chlorides. Biomass fuels may differ from each other and the composition of flue gas depends on the type of biomass during combustion. The main component of ash is $\mathrm{Ca}, \mathrm{K}, \mathrm{Si}, \mathrm{Mg}, \mathrm{Mn}, \mathrm{Al}, \mathrm{Fe}, \mathrm{P}, \mathrm{Na}$ and $\mathrm{Zn}$. Due to the fact that biomass fuels have little concentration of sulphur in comparison to hard coal they emit lower amounts of $\mathrm{SO}_{2}$ when they are fired and cofired as blends. Co-firing of biomass with coal allows us also to pay less carbon tax due to lower $\mathrm{CO}_{2}$ emission [4].

The IEA Greenhouse Gas R\&D Programme (IEAGHG) [3] estimated the potential advantage of biomass fired power plant with post-combustion capture of $\mathrm{CO}_{2}$. The study focused on techno-economic evaluation of different cases of biomass combustion and biomass co-firing power plants with and without $\mathrm{CO}_{2}$ capture. The economic analysis of electric power production was based on the following cost: total investment, coal and biomass, Green Certificates and the ETS. The analysis showed that in case the ETS value rises according to the forecasts from 2030 [7], the existing biomass-fired or co-fired power plant with $\mathrm{CO}_{2}$ capture will be comparable to power plants without $\mathrm{CO}_{2}$ capture.

The use of biomass for energy production and conversion to other products plays an important role in Bio-CCS technology nowadays. Bio-CCS is used in many different facilities from the power, industrial and fuel sectors. It delivers power and heat- helps the atmospheric carbon dioxide recycling and does not contribute to negative emissions technologies (NETs).
Moreover, biomass allows thermo-chemical and biochemical production of biofuels such us biomethane, bioethane or lignocelulosis.

The IEAGHG studies [8] estimated a technical and economic potential of Bio-CCS about $10 \mathrm{GtCO}_{2} / \mathrm{yr}$ in 2050. The following Bio-CCS routes included: biomass integrated gasification combined cycle with CCS (BIGCC-CCS), circulating fluidised bed combustion with CCS (CFB-CCS), integrated gasification combined cycle with CCS (IGCC-CCS), and pulverised coal fired power plant with CCS (PC-CCS). Post-combustion capture with chemical absorption is very extended technology for removing $\mathrm{CO}_{2}$ from industrial flue gases. The most popular absorbent used in this process is aqueous solution of monoethanolamine (MEA). This technology is well-known and advanced but requires high regeneration energy. The MEA-based $\mathrm{CO}_{2}$ capture presents also many problems such as equipment corrosion and amine degradation [9].

Oxygen and impurities contained in flue gas: acid gases $\left(\mathrm{SO}_{\mathrm{x}}, \mathrm{NO}_{\mathrm{x}}, \mathrm{H}_{2} \mathrm{~S}\right)$, heavy metals, dust particulates [10] as well as hydrocarbons [11] can react with the solvent and lead to many degradation products. Oxidative degradation is the dominant type of amine degradation in the post-combustion capture process (PCC) based on MEA [12]. It mainly takes place in the absorber section where oxygen concentration is more than $5 \%_{\mathrm{vol}}[13]$.

The most common amine degradation products are ammonia, formaldehyde and carboxylic acids such as acetic or oxalic one $[14,15]$. All of them reduce the $\mathrm{pH}$ of amine solution and lead to equipment corrosion or technological problems like amine losses or foaming [16]. Oxygen is also well-known source of amine oxidative degradation products $[17,18,19]$. The reactions of MEA and an organic or inorganic acids lead to formation the Heat Stable Amine Salts (HSAS) [20, 21]. According to [22] even a small amount of HSS may lead to amine degradation so the concentration of them in MEA solution should not be more than $500 \mathrm{ppm}$. To avoid amine degradation and losing expensive solvent the concentration of $\mathrm{SO}_{\mathrm{x}}$ in the flue gases should not exceed $10 \mathrm{ppm}$ [23].

The study of flue gas composition during biomass combustion and co-firing has not been widely published yet, but may show the advantages and disadvantages of the Bio-CCS and its influence on $\mathrm{CO}_{2}$ post-combustion capture system.

Although no post-combustion capture units have been installed yet at full scale, large demonstration projects based on amine scrubbing are being prepared. Combining biomass with CCS technologies (Bio-CCS), gasification for power production and conversion to biofuels are the promising technology routes in the power and transport sectors up to 2030 and 2050.

\section{Material and methods}

\subsection{Material}

One Polish hard coal (samples nos. C) provided by Ziemowit coal mine and the following biomass samples: 
Helianthus Tuberosus, Salix Viminalis, olive residues (Olea europaea.), and Sida Hermaphrodita - denoted as samples nos. $\mathrm{CB} 1, \mathrm{CB} 2, \mathrm{CB} 3$ and $\mathrm{CB} 4$, respectively were used in the study presented. A sample of $10 \mathrm{~g}$ of hard coal or its blends were prepared in accordance with the PN-G-04506:1996 standard. Prior to the analysis, the fuels were grounded using mill with a particle size between 1 and $3 \mathrm{~mm}$ and dried in the oven at $105^{\circ} \mathrm{C}$ for $24 \mathrm{~h}$ in order to remove moisture.

The physico-chemical parameters included: total moisture, ash, volatiles and elemental composition such as total sulphur, carbon, hydrogen, nitrogen and oxygen were determined by the accredited Laboratory of the Department of Solid Fuels Quality Assessment of the Central Mining Institute. The results were shown in Table 1. The elemental composition of coal and biomass was the same but biomass contained more oxygen, total moisture, volatiles, hydrogen and nitrogen compared to coal samples. The amount of biomass total sulfur was almost four times lower than a coal sample.

Table 1. Physical and chemical characteristics of the studied fuels.

\begin{tabular}{|l|c|c|c|c|c|}
\hline \multirow{2}{*}{ Parameter } & \multicolumn{5}{|c|}{ Fuel sample } \\
\cline { 2 - 6 } & $\mathbf{C}$ & $\mathbf{B 1}$ & $\mathbf{B} 2$ & $\mathbf{B 3}$ & $\mathbf{B} 4$ \\
\hline $\begin{array}{l}\text { Moisture content, } W^{\mathrm{a}}, \\
\% \mathrm{wt}\end{array}$ & 11.49 & 8.37 & 4.74 & 7.54 & 8.76 \\
\hline $\begin{array}{l}\text { Ash content, } A^{\mathrm{a}}, \\
\% \mathrm{wt}\end{array}$ & 5.42 & 5.93 & 1.51 & 4.11 & 2.63 \\
\hline $\begin{array}{l}\text { Volatiles content, } V^{\mathrm{a}}, \\
\% \mathrm{wt}\end{array}$ & 32.31 & 66.81 & 73.16 & 77.50 & 71.47 \\
\hline $\begin{array}{l}\text { Total sulphur content, } \mathrm{S}_{\mathrm{t}}^{\mathrm{a}}, \\
\% \mathrm{wt}\end{array}$ & 1.32 & 0.26 & 0.05 & 0.05 & 0.04 \\
\hline $\begin{array}{l}\text { Carbon content, } \mathrm{C}_{\mathrm{t}}^{\mathrm{a}}, \\
\% \mathrm{wt}\end{array}$ & 64.90 & 46.16 & 52.19 & 49.93 & 47.18 \\
\hline $\begin{array}{l}\text { Hydrogen content, } \mathrm{H}_{\mathrm{t}}^{\mathrm{a}}, \\
\% \mathrm{wt}\end{array}$ & 3.63 & 5.55 & 6.22 & 6.21 & 5.68 \\
\hline $\begin{array}{l}\text { Nitrogen content, } \mathrm{N}^{\mathrm{a}}, \\
\% \mathrm{wt}\end{array}$ & 0.96 & 1.71 & $<\mathrm{LD}$ & 1.59 & $<\mathrm{LD}$ \\
\hline $\begin{array}{l}\text { Oxygen content, } \mathrm{O}^{\mathrm{a}}, \\
\% \mathrm{wt}\end{array}$ & 13.24 & 32.28 & 35.29 & 42.04 & 35.73 \\
\hline
\end{tabular}

C-hard coal, Biomass: B1-Helianthus Tuberosus, B2-Salix Viminalis, B3-Olea europaea, B4-Sida Hermaphrodita; ${ }_{-}$ analytical state, $<$ LD-below the limit of detection.

A $10 \mathrm{~g}$ sample of hard coal and its biomass blends was placed at the bottom of the reactor at a ratio of 10 , 20, 30 and $40 \% \mathrm{w} / \mathrm{w}$ for B1 and $20 \% \mathrm{w} / \mathrm{w}$ for B2, B3 and $\mathrm{B} 4$ respectively.

\subsection{Methods}

The tests were conducted in the laboratory scale fixed bed reactor set-up of the Laboratory of Advanced Energy Technologies, the Department of Energy Saving and Air Protection of the Central Mining Institute [24, 25] (Fig. 1).

The compositions of dry and clean samples of synthesis gas were analysed automatically via the twochannel gas chromatograph, Agilent 3000A included in two thermal conductivity detectors (TDC). The PLOT U column with TCD1A detector was applied for separation of $\mathrm{CO}_{2}, \mathrm{C}_{2} \mathrm{H}_{6}$ and $\mathrm{H}_{2} \mathrm{~S}$. The MS5A PLOT column with TCD2A detector was applied for separation of $\mathrm{H}_{2}, \mathrm{O}_{2}$, $\mathrm{N}_{2}, \mathrm{CH}_{4}$ and $\mathrm{CO}$. Helium and argon were used as the carrier gases in two columns, respectively.

To protect the sample against an entrainment by the gaseous media and for the better temperature distribution, coal and coal blends samples was placed at the bottom of the reactor between quartz wool.

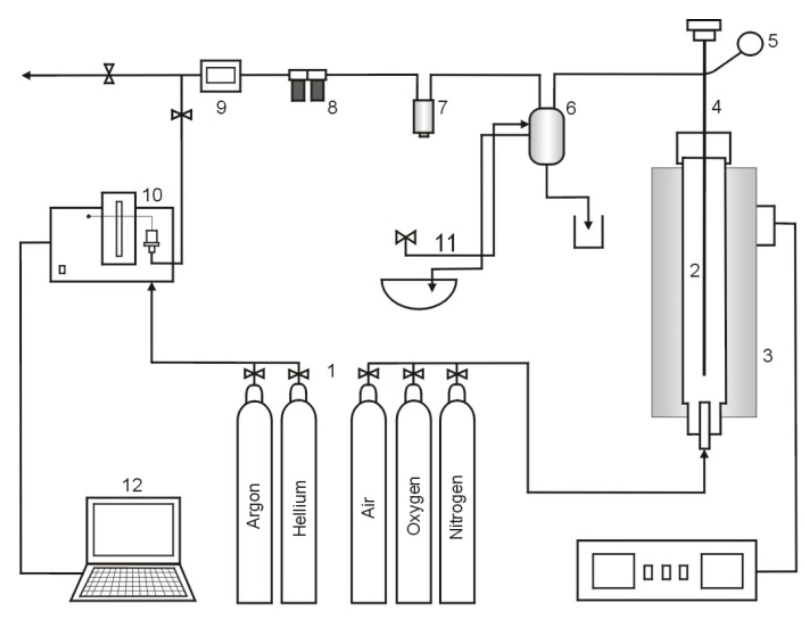

Fig.1. The laboratory-scale fixed bed reactor installation for coal combustion and gasification: 1-gases inlets, 2-fixed bed reactor, 3-resistance furnace, 4-thermocouple, 5-manometer, 6- water trap,7-solid particles filter, 8-gas dehumidifilter, 9-mass flow meter, 10-gas chromatograph, 11-gas cooling water system, 12-computer.

The reactor was heated up at a rate of $1.33^{\circ} \mathrm{C} / \mathrm{s}$ to the temperature of $900^{\circ} \mathrm{C}$ in the air atmosphere and with flow $(90 \pm 6) \times 10^{-3} \mathrm{~cm} \mathrm{~s}^{-1}$.

The amount of air required for the complete combustion of the selected carbon sample and its biomass blends was calculated stoichiometrically.

The oxygen concentration is closely related to the flow rate of air supplied to the coal boiler and the excess air fuel ratio (AFR). The value of the excess AFR depends primarily on the type of fuel combusted, the combustion process as well as the design of the boiler. Changing the excess AFR results in the amount of gas products combustion. Insufficient amount of air causes the formation of carbon monoxide and hydrocarbon, whereas excess of air leads to nitrogen oxides emission. For the total combustion, the tested samples of the AFR ratio was within the range 1.3-1.4.

Before the gas composition was analysed with the GC, the outlet gas was cooled and dried from liquid products in the water trap. The amount of gaseous products mixture $\left(\mathrm{O}_{2}, \mathrm{H}_{2}, \mathrm{CO}, \mathrm{CO}_{2}, \mathrm{CH}_{4}, \mathrm{C}_{2} \mathrm{H}_{6}, \mathrm{H}_{2} \mathrm{~S}\right)$ was measured with the mass flow meter. Time-interval length resulting from the settings of the chromatographic method was 240s. The number of time intervals during the experiment for each sample was 16 .

The volume values of the individual gas components of in the co-firing process of coal with biomass $\mathrm{V}_{\mathrm{c}}$ was calculated from the equation (1): 


$$
V_{c}=\sum_{i=1}^{n} \frac{C_{c i} F_{i}}{100} t_{i}
$$

where:

$V_{c}-$ value of $i_{\text {-th }}$ gas component obtained during the experiment, $\mathrm{m}^{3}$

$C_{c i}-$ volume concentration of $\mathrm{c}_{\text {-th }}$ gas component in $\mathrm{i}_{\text {-th }}$ time interval, \% vol.

$F_{i}$ - gas flow rate in $\mathrm{i}_{\text {-th }}$ time interval, $\mathrm{m}^{3} \mathrm{~s}^{-1}$

$t_{i}$ - length of $i_{\text {-th }}$ time interval, $\mathrm{s}$

$n$ - number of time intervals during the experiment.

\section{RESULTS AND DISCUSSION}

\subsection{Influence of biomass type on gaseous product in co-firing process}

The temperature inside the reactor measured for each tested fuel sample was comparable and was within the range of $70-930^{\circ} \mathrm{C}$. The first flue-gas samples were determined 240 seconds after the start of the combustion process and contained significant amounts of airborne oxygen. Therefore, for a comparative analysis of fluegas composition, a time interval of 720-2880s was adopted, corresponding to the combustion temperature of about $250-850^{\circ} \mathrm{C}$. The temperature increase during the experiment for each examined sample was comparable as shown in Fig. 2.

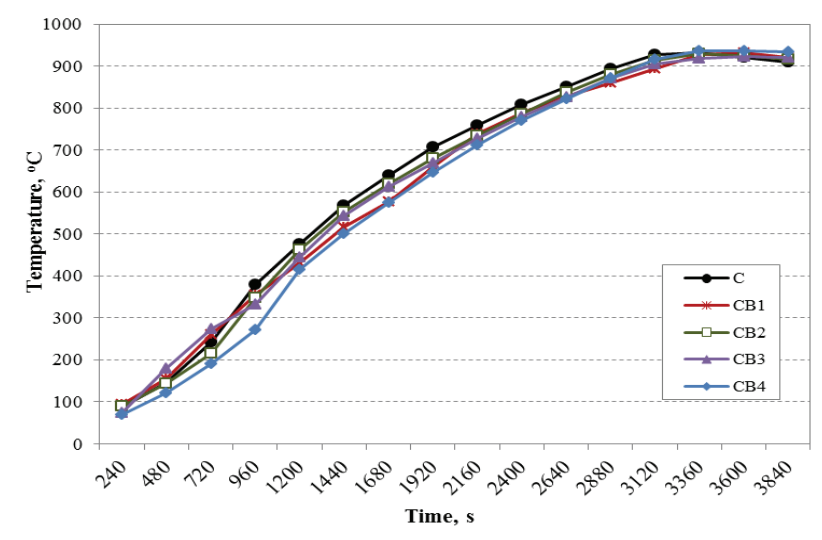

Fig.2. Temperature increase inside the reactor during the experiment for the tested fuel samples.

The main components of the gases released during the co-firing of coal and biomass blends were $\mathrm{CO}_{2}, \mathrm{CO}$, $\mathrm{O}_{2}$ and $\mathrm{N}_{2}$. There was also less $\mathrm{C}_{2} \mathrm{H}_{6}$ and $\mathrm{H}_{2}, \mathrm{H}_{2} \mathrm{~S}$ and other components, i.e. hydrocarbons, sulphur and nitrogen oxides. The measured maximum concentration of $\mathrm{CO}_{2}$ for the pure carbon sample during the tested time interval was up to $16.8 \%$ vol., and it was close to the maximum concentration of $\mathrm{CO}_{2}$ emitted during combustion of coal blends with biomass CB1, CB2, CB3 and $\mathrm{CB} 4$, that is $15.4 \%$ vol., $17.0 \%$ vol., $18.2 \%$ vol. and $16.8 \%$ vol., respectively. The change in $\mathrm{CO}_{2}$ concentration during the experiment is shown in Fig. 3. In the $\mathrm{CO}_{2}$ capture process using post-combustion method, the oxygen content in the flue gas has the greatest impact on the MEA degradation process.
In the $\mathrm{CO}_{2}$ capture process using post-combustion method, the oxygen content in the flue gas has the greatest impact on the MEA degradation process.

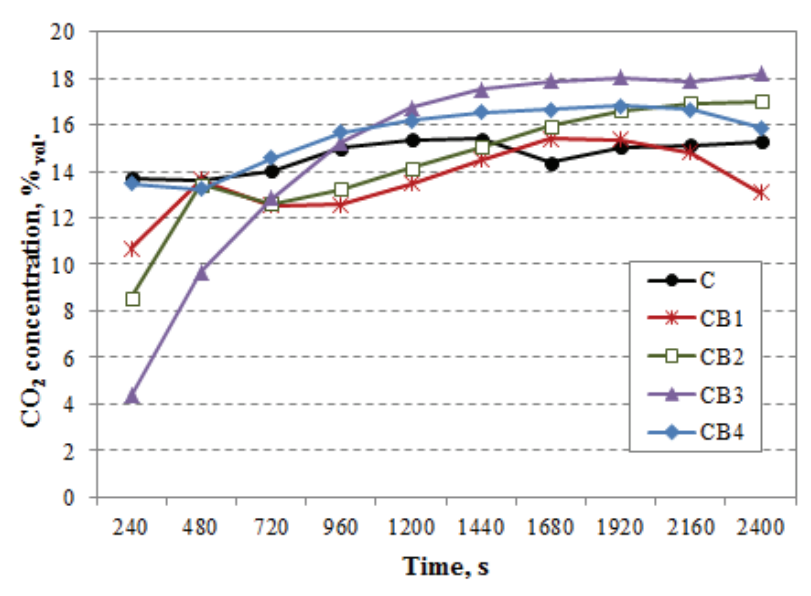

Fig. 3. Change in carbon dioxide concentration over time for the tested fuel samples.

The analysis of oxygen concentration during the experiment showed its slight increase during the combustion of coal and biomass blends in comparison with the coal sample. Most of the oxygen in the range of $250-850^{\circ} \mathrm{C}$ was obtained for $\mathrm{BC} 3$ mixture. It was related to the chemical composition of biomass as well as its ash and moisture contents. As shown in Fig. 4, all biomass blends burned more slowly, and the loss of oxygen was slower.

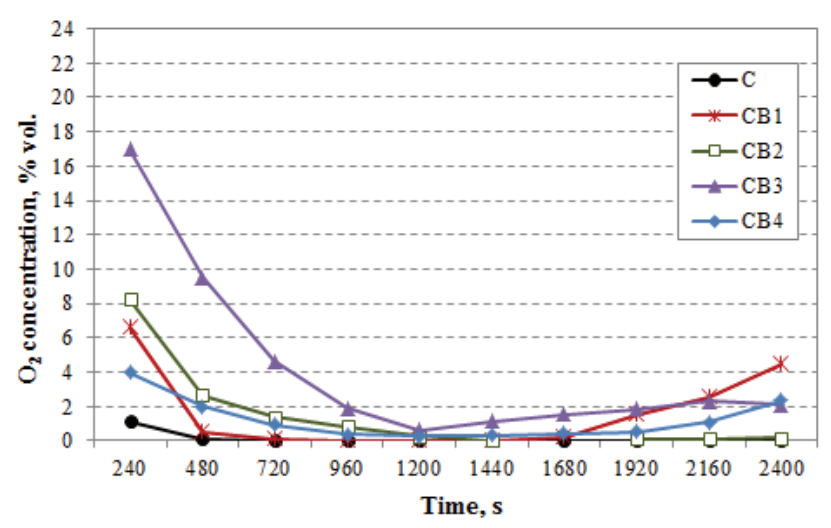

Fig. 4. Change in oxygen concentration over time for the tested fuel samples.

Taking into account the fact that the degradation of the MEA solution in the post-combustion process starts only with the oxygen content in the flue gases above $5 \%$ vol., it can be stated that the combustion of the coal-biomass blends will not affect significantly the increase in the rate of amine oxidative degradation of amine solution. The mean concentration of gaseous products, excluding nitrogen, is shown in Fig. 5, and the volume of all gaseous products and the total volume of gas blends $V_{c}$ calculated from the equation (1) are shown in Table 2.

The analysis showed that methane content in the combusted coal sample was $1.9 \%$ vol, and the presence of this component in the gases after combustion of coal and biomass blends was within the range of $1.8-2.5 \%$. 


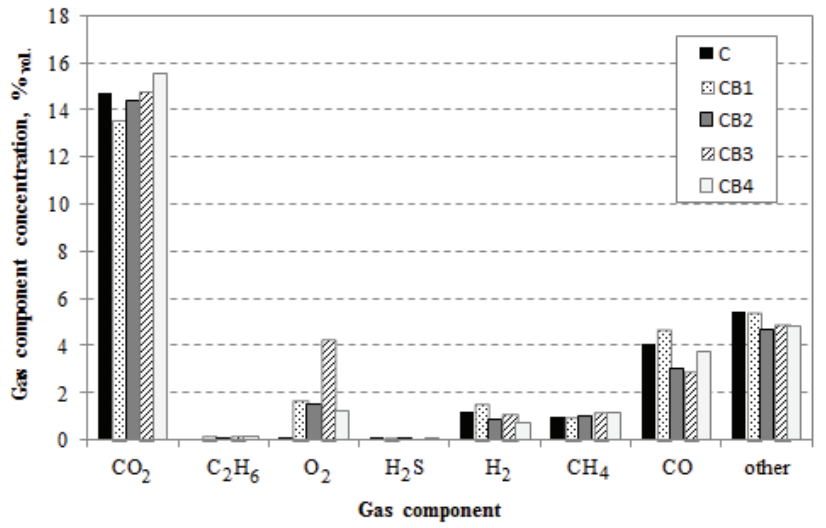

Fig. 5. Average concentration of gas components for the tested coal and biomass blends.

The content of $\mathrm{C}_{2} \mathrm{H}_{6}$ in all combusted samples was close to zero.

In the combustion processes of solid fuels, its sulphur content is converted into hydrogen sulphide and sulphur oxides. The technology of $\mathrm{CO}_{2}$ capture process using amine method is very sensitive to the sulphur content in flue gases and the permissible $\mathrm{SO}_{\mathrm{x}}$ level should not exceed 10ppm. Because of the low share of sulphur in the chemical composition of biomass compared to the pure carbon sample, the concentration of $\mathrm{H}_{2} \mathrm{~S}$ in biomass blends flue gas (0.03-0.04\% vol.) was three times lower than in the sample of the combusted coal $(0.13 \%$ vol.). Based on this analysis, it can be stated that the biomass content in the tested fuel blends will also have an impact on the reduction of sulphur oxides whose presence above $10 \mathrm{ppm}$ is one of the main causes of MEA degradation.

Table 2. Volume of individual gas components and total volume of gas for the tested coal and biomass blends.

\begin{tabular}{|c|c|c|c|c|c|}
\hline \multirow{2}{*}{$\begin{array}{c}\text { Gas } \\
\text { component }\end{array}$} & \multicolumn{5}{|c|}{ Volume, $\mathbf{1 0}^{-\mathbf{3}} \mathbf{~}^{\mathbf{3}}$} \\
\cline { 2 - 6 } $\mathbf{C O}_{\mathbf{2}}$ & 4.99 & 5.22 & 4.85 & 5.41 & 5.78 \\
\hline $\mathbf{C}_{\mathbf{2}} \mathbf{H}_{\mathbf{6}}$ & 0.01 & 0.01 & 0.01 & 0.02 & 0.01 \\
\hline $\mathbf{O}_{\mathbf{2}}$ & 0.04 & 0.56 & 0.49 & 1.60 & 0.46 \\
\hline $\mathbf{N}_{\mathbf{2}}$ & 25.15 & 28.45 & 25.88 & 27.11 & 28.04 \\
\hline $\mathbf{H}_{\mathbf{2}} \mathbf{S}$ & 0.03 & 0.00 & 0.00 & 0.00 & 0.00 \\
\hline $\mathbf{H}_{\mathbf{2}}$ & 0.42 & 0.36 & 0.24 & 0.2 & 0.18 \\
\hline $\mathbf{C H}_{\mathbf{4}}$ & 0.14 & 0.11 & 0.13 & 0.17 & 0.18 \\
\hline $\mathbf{C O}$ & 1.37 & 1.16 & 0.95 & 0.33 & 0.29 \\
\hline other $^{\mathbf{n y y y y y}}$ & 1.86 & 2.05 & 1.60 & 1.78 & 2.24 \\
\hline $\mathbf{V}_{\mathbf{c .}} \mathbf{m}^{\mathbf{3}}$ & 34.00 & 37.88 & 34.20 & 36.60 & 37.16 \\
\hline
\end{tabular}

Due to the fact that $\mathrm{H}_{2}$ and $\mathrm{CO}$ do not affect amine degradation process, they were not analysed more extensively. It was noted, however, that the presence of biomass in fuel blends reduced their content in flue gases.

For most biomass and coal blends, the increase in the total volume of flue gas was observed. The relative increase in total volume of gas for CB1, CB3 and CB4 samples in relation to pure carbon sample C was $11 \%$, $8 \%$ and $9 \%$, respectively. For the sample CB2, the total volume of gas was comparable.

\subsection{Influence of biomass concentration on gaseous product in co-firing process}

The research results of co-firing the selected coal and biomass type (Helianthus Tuberosus) with 20, 30 and $40 \% \mathrm{w} / \mathrm{w}$ are presented in Fig. 6. For a better comparison of the obtained results, only flue gas samples were analysed within the temperature range of 350$850^{\circ} \mathrm{C}$ when the amount of gaseous products was the highest.

The differences in concentrations of individual gas components were observed regarding the amount of combusted biomass. The average concentration and volume of carbon dioxide for all fuel blends were comparable. It was noted, however, that the share of other gaseous products increased or decreased depending on the biomass concentration. The biggest upward trend has been visible in the case of oxygen. The mean concentration of this component in the analysed time interval was $1.61 \%$ vol. for the sample with a biomass content of $20 \% \mathrm{w} / \mathrm{w}$ and 3.10 and $4.98 \%$ vol. for the remaining samples respectively. With the increase in the amount of biomass in the sample, the amount of hydrocarbons in the flue gas decreased. The average concentration of $\mathrm{CH}_{4}$ was $0.96,0.32$ and $0.00 \%$ vol. and the concentration of $\mathrm{C}_{2} \mathrm{H}_{6}$ was $0.10,0.03$ and $0.00 \%$ vol., respectively. The downward concentration trend was also observed for $\mathrm{H}_{2} \mathrm{~S}\left(0.04,0.02,0.00 \%\right.$ vol.), $\mathrm{H}_{2}$ (1.50, $0.46,0.02 \%$ vol. $), \mathrm{CO}(4.70,1.11,0.15 \%$ vol. $)$ and the remaining gases $(5.38,4.77,2.25 \%$ vol. $)$.

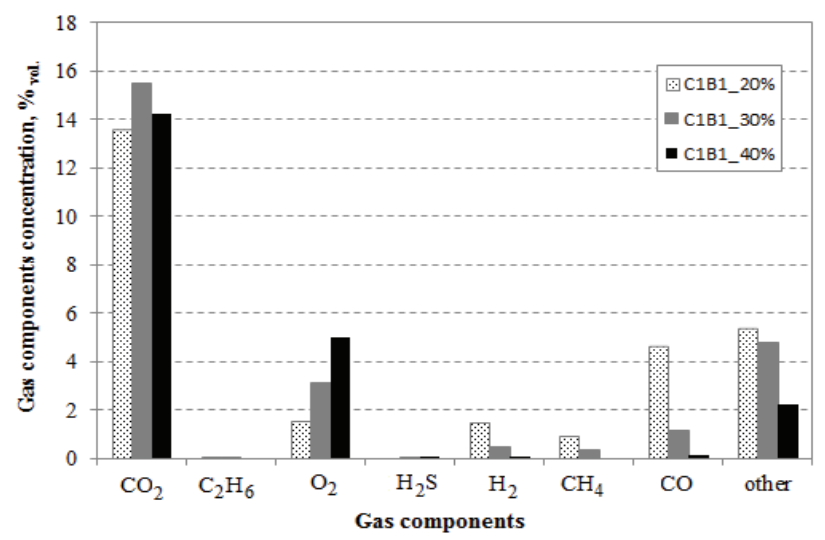

Fig. 6. Average concentration of gas components for the analysed coal and biomass blends.

The volume of the individual gas components and the total volume are shown in Table 3.

As shown in the Table 3, the increase in the percentage share of biomass in the fuel resulted in a decrease in the total volume of the separated gas. Compared to the CB1_20\% sample, the volume decrease was $11 \%$ for CB1_30\% and $18 \%$ for CB1_40\%. 
Table 3. Volume of individual gas components and total volume of gas for the tested coal and biomass blends.

\begin{tabular}{|c|c|c|c|}
\hline \multirow{2}{*}{$\begin{array}{c}\text { Gas } \\
\text { component }\end{array}$} & \multicolumn{3}{|c|}{ Volume, $10^{-3} \mathrm{~m}^{3}$} \\
\hline & CB1_20\% & CB1_30\% & CB1_40\% \\
\hline $\mathrm{CO}_{2}$ & 5.22 & 5.21 & 4.39 \\
\hline $\mathrm{C}_{2} \mathrm{H}_{6}$ & 0.01 & 0.01 & 0.00 \\
\hline $\mathrm{O}_{2}$ & 0.56 & 1.04 & 1.52 \\
\hline $\mathrm{N}_{2}$ & 28.45 & 25.06 & 24,17 \\
\hline $\mathrm{H}_{2} \mathrm{~S}$ & 0.00 & 0.00 & 0.00 \\
\hline $\mathrm{H}_{2}$ & 0.36 & 0.15 & 0.01 \\
\hline $\mathrm{CH}_{4}$ & 0.11 & 0.11 & 0.00 \\
\hline $\mathrm{CO}$ & 1.16 & 0.37 & 0.05 \\
\hline other & 2.05 & 1.59 & 0.07 \\
\hline $\mathrm{V}_{\mathrm{c}}$ & 37.88 & 33.60 & 30.84 \\
\hline
\end{tabular}

\section{Conclusions}

The conducted studies showed no increased impact of amine solvent degradation on $\mathrm{CO}_{2}$ capture process using post-combustion method.

During co-firing of coal with biomass energy crops in the amount up to $20 \% \mathrm{w} / \mathrm{w}$, there is a similar percentage of gaseous products as in the case of pure coal combustion. The oxygen content which contributes to amine degradation is comparable to the various types of biomass and safe for the process to be conducted properly. With an increase in the share of biomass in fuel mixtures, the average oxygen concentration and its volume in the total gas increases proportionately to the amount of biomass. Such flue gas blends subjected to carbon dioxide capture process should be controlled for the risk of oxidative degradation.

The advantage of using an increased amount of biomass is the low emission of sulphur-containing gases as well as the reduced amount of hydrocarbons. All these compounds also have an effect on amine degradation, that is why their reduced content in flue gases has a beneficial effect on the $\mathrm{CO}_{2}$ capture. The conducted studies also showed that the increase in the share of biomass to coal in the range of $30-40 \% \mathrm{w} / \mathrm{w}$ results in an increase in the total volume of flue gas by $11-18 \%$ compared to blends containing $20 \% \mathrm{w} / \mathrm{w}$ of biomass, with similar $\mathrm{CO}_{2}$ emission.

The results of this research indicate the beneficial effect of the post-combustion method integrated with a biomass-fired power plant.

\section{Acknowledgments}

This work was supported by the Ministry of Science and Higher Education. Poland. under Grant no. 11100117.

\section{References}

1. A. Demirbas, Progress Energy Combust. Sci. 30, 219 (2004)

2. EBTP-ZEP, Biomass with $\mathrm{CO}_{2}$ Capture and Storage (Bio-CCS ). The way forward for Europe (2012)

3. R. Domenichini, F. Gasparini, P. Cotone, S. Santos, Energy Procedia 4, 1851 (2011)
4. Z. Khorshidi, M. T. Ho, and D. E. Wiley, Energy Procedia 37, 6035 (2013)

5. ZEP, The costs of $\mathrm{CO}_{2}$ capture, transport and storage: Post-demonstration CCS in the EU, European Technology Platform for Zero Emission Fossil Fuel Power Plants, 2011

6. Regulation of the Minister of Environmental Protection, Monitor Polski 718 (2016) [in Polish]

7. P. Luckow, E. A. Stanton, S. Fields, W. Ong, B. Biewald, S. Jackson, J. Fisher, Spring 2016 National Carbon Dioxide Price Forecast. Synapse Energy Economics, 2016

8. J. Kemper, Int. J. Greenhouse Gas Control 40, 401 (2015)

9. A. Krzemień, A. Więckol-Ryk, A. Smoliński, A. Koteras, L. Więcław-Solny, J. Loss Prev. Process Ind. 43, 189 (2016)

10. D. Adams, Flue gas treatment for $\mathrm{CO}_{2}$ capture. IEA Clean Coal Centre, CCC/169 (2010)

11. F. S. Manning, R. E. Thompson, Oilfield Processing of Petroleum: Natural gas (PellWell Publishing Company Tusla, Oklahoma, 1991)

12. C. Susan, T. Rochelle First National Conference on Carbon Sequestration Austin, Texas, 2001

13. J. Kittel, E. Fleury, B. Vuillemin, S. Gonzalez, F. Ropital, R. Oltra, Mater. Corros. 63, 3, 223 (2012)

14. G. S. Goff, G.T. Rochelle, Ind. Eng. Chem. Res. 43, 6400 (2004)

15. S. B. Fredriksen, K-J. Jens. Energy Procedia 37, 1770 (2013)

16. N. Verma, A. Verama, Fuel Proces. Technol. 90, 483-489 (2009)

17. H. Lepaumiera, E.F. da Silva, A. Einbu, A. Grimstvedt, J. N. Knudsen, K. Zahlsen, H. F. Svendsen, Energy Procedia 4, 1652 (2011)

18. C. Gouedard, D. Picq, F. Launay, P. L. Carrette, Int. J. Greenh. Gas Control 10, 244 (2012)

19. S. J. Vevelstada, A. Grimstvedtb, J. Elnana, E. F. da Silva., H. F. Svendsena, Int. J. Greenhouse Gas Control 18, 88 (2013)

20. A. L. Kohl, R. B. Nielsen, Gas purification - Fifth Edition (Gulf Publishing Company, Houston, Texas, 1997)

21. T. Supap, R. Idem, and P. Tontiwachwuthikul, Energy Procedia 4, 591 (2011)

22. P. C. Rooney, T. R. Bacon, M. S. DuPart, Hydrocarb. Process. 75, 3, 95 (1996)

23. R. M. Davidson, Post-combustion carbon capture from coal fired plants - solvent scrubbing (IEA Clean Coal Centre, CCC/125, 2007)

24. A. Smoliński, N. Howaniec, K. Stańczyk, Renew. Energy 36, 1836 (2011)

25. A. Smoliński, Energy Convers. Manag. 52, 37 (2011) 